\title{
The Moral Education in Chinese Teaching of Minority Preparatory University
}

\author{
Qinxi $\mathrm{Wu}^{1, \mathrm{a}}$ \\ ${ }^{1}$ Nanchang Institute of Science \&Technology, Nanchang, Jiangxi, 330108 \\ ${ }^{\mathrm{a}}$ email
}

Keywords: Minority Preparatory, Preparatory University Chinese, Moral Infiltration

\begin{abstract}
In the context of the current quality of education, students' moral education has more and more people's attention. University language teaching materials is one of many disciplines involved in the education factor a curriculum most widely used, language subjects itself has a certain humanism and ideology, which also resulted in its conduct moral duties. Penetration of moral education in the language teaching process, allowing effective enhancement of Chinese Quality Education and realize the goal of teaching. But in the process of language teaching minority preparatory college, you want to achieve moral purpose, to rely solely on traditional didactic way is clear that there is very difficult, therefore, which requires Chinese Teaching Minority Preparatory college moral methods and measures discuss in depth. This paper studies above characteristics and hope to bring some reference for Chinese Teaching of National Minority Preparatory College Moral penetration.
\end{abstract}

\section{Introduction}

The classroom is an important venue minority students to engage in moral education, moral education in minority teaching activities in Moral Education has a very important significance. How to effectively combine their language and teaching moral education, students realize the moral purpose of culture is one of the important issues of the moment many language teachers have to think. Minority language teaching in university matriculation, Moral Education allows students to develop a comprehensive and effective sustainability needs are met, but also an important requirement of the new curriculum. Minority Preparatory College Chinese textbook has a rich tradition of excellence ideas and theories, its unique advantages in the teaching process, the constant infiltration of moral education for students of moral improvement, and establish a correct outlook has three very important help.

\section{Moral Penetration from the Text and Its Background}

Minority Preparatory College Chinese Course in every article, are created by the writer in a specific historical background out of the writing of the text background in detail, not only allows students to get deeper understanding of the text, but also can promote moral education students receive unknowingly. Secondly, the title of the article is the key to the whole article, which can be directly or indirectly the subject of this article is to show the reader, in the title of the article is analyzed from two perspectives need to be on one of its literal meaning, the second is the deep meaning inherent in [1]. Chinese Course background and title of each article, the teaching process is an important learning point, so the teacher can in this teaching process, subtle Moral Thought. For example: In a one-year preparatory textbook, teachers explain the "snow in the land of China," the article, you can start with the title moral education penetration, allow students to discuss their own "snow" mean, There are pieces of text in the picture, They represent, Author in creating mood and how. Through these few simple questions, encourage students to enter from the emotional point of view to study the text. Then teachers to students about their background: Ai Qing at December 28, 1937 came to Wuhan, after the Marco Polo Bridge Incident, the anti-Japanese people thought the country is growing, but in fact, the KMT was in constant retreat, turn vast territory instantly lost half. At this time of national survival, people on the one hand to explore ways to win, on the other 
hand the reality of losing ground in the vast China will be how the tiny Japanese fall into deep pain while thinking. Ai Qing, as a deep concern for the future and destiny of the motherland of poets, can only be a unique way to express their feelings.

The entire article by farmers, as well as the mother of the young woman under the snow image for detailed description, to show up at the time of the Chinese nation suffered disaster and suffering, the full expression of the poet's strong patriotism. Through the introduction of the article title and the background of the student to bring that era to feel the author of patriotism in order to influence each student, so that students learn how to love their country, their loved ones around the considerate .

\section{The Combination of Classroom Performance of Moral Penetration}

Classroom teaching allows students to show interest in learning to get excited, carried out in the course of Moral Education can play a more significant effect. During the process of teacher education, it should be a lot of flexibility in the use of teaching methods, classroom performance through the integrated use of teaching methods do achieve subtle moral education penetration target [2]. For example: In the first year of preparatory language teaching system "Peach Blossom Fan • but Lian" the teaching process, in order to allow students to truly master the content of the text, teachers can organize students to perform, in the performance of the process, guiding students as possible use body language to show the author's mood, however, so that students in a relaxed performance teaching process, showing the real content of the liberal arts, and thus more deeply appreciate the resolute character of author Li Xiangjun anxious patriotism.

\section{Make Moral Education in the Text Read}

Students read aloud the text, can vividly express the content of the article, so that it can be more in-depth understanding of the many article ideas. In the reading process, we want to grasp the main idea, some carriers require students to recite their emotions, which will accurately convey ideas to the audience the work [3]. For example: In a one-year preparatory textbook "<Mencius $>$ election" process of teaching, in the recitation of the five sections of selected text, teachers should guide students to the different characteristics of the purpose of the article to be effective control, by changing the tone and speech rate truly grasp the idea of Mencius, wisdom and charisma. Another example: In the study "Eight Poems" and " Teach fishes" and other articles and poems, read by means of not only enable students to appreciate the poet in the creation of works exhibited in the future of the country and concerns and love, and also allows students to train students noble sentiments, encourage students good study habits and interests to be formed, so let correct outlook on life, values, and worldview can be effectively established.

\section{Moral Education in Text Brief and Its Summary}

Brief summary of the text and allows students to do further analysis of the problem and research, is one of the main ways in which the process of teaching Moral Education [4]. Analysis of the text and summarize the main points is a text-based knowledge by teachers purposefully Brief summary and the central idea of the text and important content to students can effectively deliver the correct mindset and character education. For example: In the study "sun off the snow" when the teacher can text summary is set to a question: "What scenery and purpose of comparison in front of the restored historical truth is?" After students through discussion, teachers in the students discussed the the results are summarized:. "wrote the author to be more highlighted the sense of regret" and teachers during the entire article concluding summary, the author of the death of civilization and regret, and in turn how to properly treat our nation's many cultures heritage, how should we do it effectively inherited and carried forward. Thereby to allow students a love for the motherland can be fully excited. 


\section{Emotional Penetration}

Emotional penetration in the subject and the background above-described penetration somewhat similar, which is designed to allow teachers in the process of language teaching, so that students and writers across time and space of dialogue, proximity author, understand what the author, and text-depth dialogue, at the same time teachers should use real emotions, to infect and inspire students, prompting the students can and soul between teachers and authors, and texts resonate, so that students in learning the language knowledge, to feel good sentiment, and then showing a noble and a healthy emotional moral infiltration method [5]. Emotional penetration process, teachers want their feelings to the author, articles and student feelings organic integration in the promotion of strong emotions down so that students take the initiative to learn and explore, so that students heart and soul. For example: in the study of Du Fu 's Eight Poems "It's a poem, from three aspects: first evoked feelings. Play "Spring Hope" and other poems, and encourage students to emotion expressed by the poet resonate, providing a foundation for poetry in the master poet of patriotism; secondly to stimulate feelings. Through teaching, the use of language to convey emotion saturated verse, for students to learn and master the profound truth in this emotional boost.

\section{Enhance Teachers' Moral Accomplishment}

As the old saying: "Good knowledge is for teachers, High morality is for teachers." In the whole process of education, a wealth of knowledge just a small part of the teacher's own moral qualities of students, has a very important and direct influences. In the socio-cultural ethics, the teacher as the "spokesperson" of the responsibilities is to develop more teaching. From the student's point of view, teachers themselves is an important teaching force and teaching resources, teachers want to achieve the purpose of teaching, the first step is educating yourself. Value of diversity in the modern social context, a complete personality qualities and moral qualities has a very important role [6]. Therefore, teachers in the teaching process, from all aspects of the Moral teaching is on the one hand, on the other hand it is to do word and deed, with its noble personality and moral qualities, to establish a role model for students, which is a minority Chinese Teaching ethnic preparatory college process, one of the important methods of Moral Education.

\section{Conclusion}

All in all, the process of minority language teaching in the university matriculation, moral infiltration methods and channels varied, university teachers should based on teaching language and actively explore the penetration of moral superiority of University language subjects and accurately exhumed the Chinese language textbooks for the university moral factors inherent, find out the most appropriate way of penetration and then actively engaged in the process of teaching Moral Education, which can encourage minority students to learn and gradually become the driving force of life, so that more minority students can form noble character, to become highly qualified new era of college students.

\section{References}

[1] Wu Jinfeng. Comparative study of Xinjiang ethnic education of Ethnic Minorities Mode and the national Institute of Ethnic Preparatory Training Mode [J]. Xinjiang Normal University (Philosophy and Social Sciences), 2014, 02: 146-151.

[2] Wang Limin, Guo Ce, Wang Yunyu. Practice of build Wang Jue Minority Preparatory Students Academic Guidance System - A Case Study of Dalian Nationalities University Preparatory Education [J]. Dalian Nationalities University, 2010, 03: 265-268.

[3] Wang Ziyun. Changes are in development of innovation in the exploration - Inner Mongolia Normal Minority Preparatory Education Review and Prospect [J]. Inner Mongolia Normal University (Education Science Edition), 2014, 07: 11-13 + 30. 
[4] Ja Min. Analysis Minority Preparatory Education Evaluation System - A Case Study of Heilongjiang Province in [J]. Higher Studies, 2012, 11: 45-47.

[5] Wu Xuehui. Depth layered Minority Preparatory Education Teaching Reform - A Case Study of Nanchang Institute of Ethnic Preparatory Education [J]. Asia-Pacific Education, 2015, 35: 6-7.

[6] Peng Guorong. tentative ethnic preparatory mathematics teaching Moral Education - Taking the Hubei Institute for Nationalities Preparatory Mathematics Teaching Example [J]. Education Forum, 2016, 01: 46-47. 